MISS STEFANIA APPELHANS (Orcid ID : 0000-0001-7975-5745)

Article type : Research Paper

Soil P changes with long-term fertilization

\title{
Assessing soil $P$ fractions changes with long-term phosphorus fertilization related to crop yield of soybean and maize
}

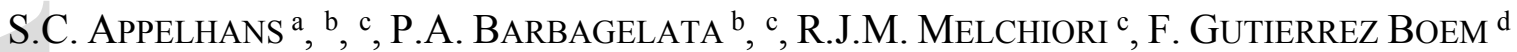

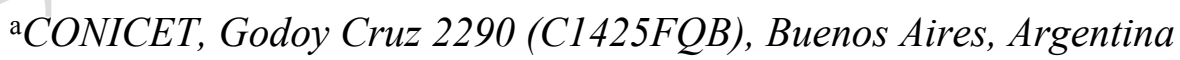

${ }^{\mathrm{b}}$ Facultad de Ciencias Agropecuarias, Universidad Nacional de Entre Ríos. Ruta $11 \mathrm{Km}$ 10,5 (3100), Paraná, Argentina

'INTA EEA Paraná, Paraná, Ruta 11, Km 12,5 (3100), Argentina

IINBA (CONICET UBA) and Soil Fertility and Fertilizers, School of Agriculture, University of Buenos Aires, Av. San Martín, (4453C1417DSE) Buenos Aires, Argentina

Correspondence: Stefania C. Appelhans. E-mail: Stefania_appelhans@hotmail.com.

This article has been accepted for publication and undergone full peer review but has not been through the copyediting, typesetting, pagination and proofreading process, which may lead to differences between this version and the Version of Record. Please cite this article as doi: 10.1111/SUM.12581-2019-134

This article is protected by copyright. All rights reserved 


\section{Abstract}

Long-term P fertilization increases soil phosphorus (P) labile fractions, which can be associated with crop P uptake and grain yield and are useful to improve fertilizer recommendations. Research aims were to evaluate in long-term experiments with different $\mathrm{P}$ fertilization in a Mollisol and a Vertisol: i) the changes of soil P fractions, and ii) the relationship between soil P fractions with long-term P fertilization, accumulated apparent P budget, grain P, total P uptake, soybean (Glycine $\max$ L.Merr.) and maize (Zea mays L.) grain yield. Soil $\mathrm{P}$ fractions were measured after 1 and $9 \mathrm{yr}$ since the beginning of long-term experiments. Experiments included an initial fertilization rate of $200 \mathrm{~kg} \mathrm{P} \mathrm{ha}^{-1}$, and annual P fertilization rate of $36 \mathrm{~kg} \mathrm{P} \mathrm{ha}^{-1}$. Bray1-P, total, organic, and inorganic $\mathrm{P}$ in fine $(<53 \mu \mathrm{m})$ and coarse $(>53 \mu \mathrm{m})(\mathrm{CF})$ soil fractions, and in $\mathrm{NaHCO}_{3}$ extract were measured. Initial $\mathrm{P}$ fertilization increased inorganic and total $\mathrm{P}$ fractions. Whereas, Brayl-P, total $\mathrm{P}$ in $\mathrm{NaHCO}_{3}$ extract and in the CF were the fractions with most increased with continuous long-term $\mathrm{P}$ fertilization in both sites. In the Mollisol, maize grain yield was unrelated to long-term $\mathrm{P}$ fertilization. In the Vertisol, total $\mathrm{P}$ in $\mathrm{NaHCO}_{3}$ extract, and total and organic $\mathrm{P}$ in the $\mathrm{CF}$ were more closely related to soybean grain yield than Bray1-P. We proposed soil P indices of labile inorganic and organic $\mathrm{P}$ that showed close relationships with soybean grain yield and may be useful to improve the diagnosis of P soil fertility.

Keywords: organic $P$, total $P$, soil coarse fraction, apparent $P$ budget, $P$ uptake, fertilization

\section{Introduction}

Phosphorus (P) is essential for plant growth and frequently deficient in agricultural soils. Total soil $\mathrm{P}$ exceeds plant requirements, but it is mostly in non-available forms for crop uptake. Organic $\mathrm{P}$ represents 30 to $65 \%$ of total soil P (Condron et al., 2005), and releasing from soil organic matter contributes to crop P availability (Tiessen et al., 1994), especially in soils with low available inorganic P (Stewart \& Sharpley, 1987). Organic P increases in soil surface in no-till systems (Rodrigues et al., 2016), and it is composed of fractions of different lability with many methodologies to determine them (Hedley et al., 1982; Thien \& Myers, 1992; Wyngaard et al., 2013).

Total and organic $\mathrm{P}$ in the coarse soil fraction (CF) (soil fraction $>53 \mu \mathrm{m}$ ) have been reported as sensitive to continuous long-term P fertilization (Ciampitti et al., 2011b; Wyngaard et al., 2013). Total $\mathrm{P}$ in the coarse soil fraction (Pt-CF) was related to maize $\mathrm{P}$ uptake at flowering 
and suggested as an index of soil $\mathrm{P}$ availability (Ciampitti et al., 2011b). In addition, Wyngaard et al. (2016) reported that organic P in $\mathrm{CF}$ (Po-CF) was an indicator of $\mathrm{P}$ mineralization, thus a potential source of available $\mathrm{P}$ for plant growth. However, recent results did not show a relationship between soybean relative yield and Pt-CF in the Argentina Pampas Region (Appelhans et al., 2016). Consequently, as previous studies showed no concordant results, it is relevant to determine whether long-term $\mathrm{P}$ fertilization induces changes in Pt-CF and Po-CF; and whether these soil $\mathrm{P}$ fractions are related to soybean and maize total $\mathrm{P}$ uptake and grain yield. Soil $\mathrm{P}$ extracted by $\mathrm{NaHCO}_{3}$ is considered a P fraction available to crops (McDowell et al., 2008) that includes an easily mineralizable organic P fraction (Boschetti et al., 2003), and recently a study showed that was related to soybean yield (Appelhans et al., 2016).

Organic P fractions have been measured in soils with different textures, fertilization treatments, and crop sequences (Boschetti et al., 2003; McDowell et al., 2008; Negassa \& Leinweber, 2009; Appelhans et al., 2016, Rocha et al., 2016, Rodrigues et al., 2016), but they have not been related with soybean and maize P nutrition. The current soil P test used in the Argentina Pampas Region is Bray1-P, which only considers an inorganic P fraction (Steffens et al., 2010). The inclusion of labile organic $\mathrm{P}$ fractions in routine soil test $\mathrm{P}$ may improve $\mathrm{P}$ fertilizer recommendations (Dodd \& Sharpley, 2015; Appelhans et al., 2016). In this sense, assessing the changes of $\mathrm{P}$ fractions with long-term $\mathrm{P}$ fertilization may be useful to select $\mathrm{P}$ fractions related to crop grain yield.

The aims of this study were to evaluate in long-term experiments with different $\mathrm{P}$ fertilization in a Mollisol and a Vertisol: i) the changes of soil P fractions, and ii) the relationship between soil $\mathrm{P}$ fractions with long-term $\mathrm{P}$ fertilization, with accumulated apparent $\mathrm{P}$ budget, grain $\mathrm{P}$, total $\mathrm{P}$ uptake, and soybean and maize grain yield.

\section{Materials and methods}

\section{Experimental site}

The study was conducted in two long-term P fertilization experiments under no-till established in 2006 and 2007 on two sites at the Agricultural Experiment Station of INTA Paraná, Entre Ríos Province, Argentina ( $\left.31^{\circ} 50.9^{\prime} \mathrm{S} ; 60^{\circ} 32.3^{\prime} \mathrm{W}\right)$. Soils of the experimental sites were described as Mollisol (Tezanos Pinto series, fine, mixed, thermic Aquic Argiudoll), and Vertisol (Febré series fine, slightly alkaline, thermic Chromic Hapludert) (Soil Survey Staff, 2014). The region has a humid (annual rainfall $\approx 1000 \mathrm{~mm}$ ) and temperate climate (annual temperature $\approx 18.3{ }^{\circ} \mathrm{C}$ ). 
Mollisol site included a two-year crop sequence with double-cropped wheat (Triticum aestivum L.) and soybean followed by maize as a single crop; whereas, in Vertisol site, a three-year crop sequence included double-cropped wheat and soybean followed by maize and soybean as single crops.

Crop sequences differed between sites according to crop productivity of soils; Mollisol soil had higher crop productivity than Vertisol site (Novelli et al., 2017). In the Mollisol site, average annual crop productivity was $7226 \mathrm{~kg} \mathrm{ha}^{-1}$ and in the Vertisol it was $5645 \mathrm{~kg} \mathrm{ha}^{-1}$. Average annual crop productivity was calculated as the ratio of accumulated grain yield at the crop sequence level (Caviglia et al., 2019) and the duration in years of the sequence cycle. In the Mollisol site, average crop productivity was $8756 \mathrm{~kg} \mathrm{ha}^{-1}, 2663 \mathrm{~kg} \mathrm{ha}^{-1}$, and $3033 \mathrm{~kg} \mathrm{ha}^{-1}$ for maize, wheat, and soybean as double crops, respectively. In the Vertisol average crop productivity was $3493 \mathrm{~kg} \mathrm{ha}^{-1}, 7803 \mathrm{~kg}$ $\mathrm{ha}^{-1}, 2674 \mathrm{~kg} \mathrm{ha}^{-1}$, and $2964 \mathrm{~kg} \mathrm{ha}^{-1}$ for soybean as a single crop, maize, wheat and soybean as double crops, respectively.

Treatments and experimental design

At each experiment, we evaluated four treatments from a combination of two initial ( 0 and $200 \mathrm{~kg}$ $\left.\mathrm{P} \mathrm{ha}^{-1}\right)$ with two annual fertilizer-P rates $\left(0\right.$ and $\left.36 \mathrm{~kg} \mathrm{P} \mathrm{ha}^{-1}\right)$ applied as triple superphosphate. These treatments were arranged in a randomized split-plot design with four replications. Initial $\mathrm{P}$ fertilization rates were assigned to main plots ( 9.6 by $24 \mathrm{~m}$ ), and annual $\mathrm{P}$ fertilizer rates to subplots ( 4.8 by $24 \mathrm{~m}$ ). Initial P fertilizer rate was hand-broadcast applied in June 2006 for the Vertisol site, and in June 2007 for the Mollisol site. The annual P fertilization rate was handbroadcast applied in June each year and started in 2007 for both sites.

\section{Soil sampling and analysis}

Initial soil sampling to characterize sites at the beginning of each experiment was carried out before applying P in June of 2006 in the Vertisol site and 2007 in the Mollisol site. Soil samples were air-dried, ground, and passed through a 2-mm sieve. Soil texture (Gee \& Bauder, 1986), pH (Van Lierop, 1990), soil organic C (SOC) content (Walkley \& Black, 1934), and Bray1-P (Bray \&Kurtz, 1945) were determined (Table 1).

Soil sampling was also performed after a year of initial P fertilizer application in each site, and in 2016, after $9 \mathrm{yr}$ of continuous annual $\mathrm{P}$ treatments. Composite soil samples (15-20 cores per subplot) were collected at two sampling depths $(0-$ to $-5 \mathrm{~cm}$, and 5- to $-20 \mathrm{~cm})$, were air-dried, ground, and passed through a 2-mm sieve. Bray1-P, total, organic, and inorganic $\mathrm{P}$ in $\mathrm{NaHCO}_{3}$ extracts were determined. 
Inorganic and organic $\mathrm{P}$ was extracted with $\mathrm{NaHCO}_{3}$ by shaking $4 \mathrm{~g}$ of bulk soil samples with $40 \mathrm{ml}$ of $\mathrm{NaHCO}_{3} 0.5 \mathrm{M}$ for $30 \mathrm{~min}$ (1:10 soil: solution ratio) (Thien \& Myers, 1992). Then, inorganic P (Pi-Bic) was determined by colorimetry. Total extractable P (Pt-Bic) was determined by digesting an extract aliquot with $\mathrm{H}_{2} \mathrm{SO}_{4}$ and ammonium persulfate for $1 \mathrm{~h}$ at $150{ }^{\circ} \mathrm{C}$. To determine $\mathrm{P}$ content in the digest, the $\mathrm{pH}$ was corrected, and $\mathrm{P}$ concentration was measured colorimetrically (Kuo, 1990). Organic P (Po-Bic) was calculated as the difference between Pt-Bic and Pi-Bic.

Coarse and fine soil fractions were determined following the procedure described by Cambardella \& Elliott (1992), modified by Irizar et al. (2010). Briefly, 10 g soil samples were shaken with two glass balls and $30 \mathrm{~mL}$ of distilled water for $16 \mathrm{~h}$. Soil fraction that passed through the 53- $\mu \mathrm{m}$ sieve (fine soil fraction (FF)) and the soil fraction on top of the sieve (coarse soil fraction (CF)) were dried, homogenized, and ground. After extraction with $\mathrm{H}_{2} \mathrm{SO}_{4} 0.5 \mathrm{M}$ for $16 \mathrm{~h}$, inorganic $\mathrm{P}$ was measured colorimetrically in FF and $\mathrm{CF}$ (Pi-FF, and Pi-CF, respectively). Total $\mathrm{P}$ in FF and CF (Pt-FF, and Pt-CF, respectively) was determined by the ignition method (Kuo, 1990), and organic P in FF and CF (Po-FF, and Po-CF, respectively) was calculated as the difference between Pt and Pi. Values of each P fraction at 0 - to $-20 \mathrm{~cm}$ depth were calculated by weighting data from 0 - to $-5 \mathrm{~cm}$ and 5 - to $-20 \mathrm{~cm}$ depth soil samples.

\section{Crop measurements and analysis}

Shoot biomass for soybean and maize in 2016 were measured by sampling a $1 \mathrm{~m}^{2}$ area in each subplot at physiological maturity. Soybean, maize, and wheat were harvested using an experimental plot combine of $12 \mathrm{~m}^{2}$ in each subplot to separate grain yield of crop biomass. Soybean, maize, and wheat grain yield were corrected to 145,135 , and $135 \mathrm{~g} \mathrm{~kg}^{-1}$ moisture, respectively. Shoot and grain samples were dried at $65^{\circ} \mathrm{C}$ and ground to pass a $1 \mathrm{~mm}$ sieve and $\mathrm{P}$ content was determined colorimetrically after $\mathrm{HNO}_{3}-\mathrm{HClO}_{4}$ digestion (Kuo, 1990).

Soybean and maize relative yield (RY) was calculated as the ratio between the grain yield of each treatment, and grain yield of treatment with the maximum $P$ fertilizer rate (i.e. $200 \mathrm{~kg} \mathrm{ha}^{-1}$ of initial $\mathrm{P}$, and $36 \mathrm{~kg} \mathrm{ha}^{-1}$ of annual $\mathrm{P}$ ). Crops grain yield response to $\mathrm{P}$ fertilization (Response) was calculated as the difference between crop grain yield of each treatment and grain yield of the control treatment (no added P).

Accumulated long-term apparent $\mathrm{P}$ budget (9 years) was obtained by summing up the annual apparent $\mathrm{P}$ budget. Apparent $\mathrm{P}$ budget $\left(\mathrm{kg} \mathrm{ha}^{-1}\right)$ was calculated as the difference between fertilizer applied $\mathrm{P}$ and crops grain $\mathrm{P}$ uptake. Crop grain $\mathrm{P}$ uptake was calculated from grain yield 
and grain P concentration. Grain P concentration was determined for each treatment in soybean and maize in 2016, and for wheat in 2017. Average P concentration for each treatment at each site and annual yields were used to estimate grain P uptake of the previous crops. In the Mollisol, grain P concentration of soybean were 4.2, 4.5, 4.0, and 4.3 $\mathrm{mg} \mathrm{P} \mathrm{g}^{-1}$; of wheat, were 4.5, 4.8, 4.6, and $4.3 \mathrm{mg} \mathrm{P} \mathrm{g}^{-1}$; of maize were 5.2, 5.5, 5.3, and $5.03 \mathrm{mg} \mathrm{P} \mathrm{g}^{-1}$ for each treatment, respectively. In the Vertisol, grain P concentration of soybean were 3.4, 5.0, 4.2, and 5.2 $\mathrm{mg} \mathrm{P} \mathrm{g}^{-1}$; of wheat were 3.5, 5.6, 3.7, and 5.4 $\mathrm{mg} \mathrm{P} \mathrm{g}^{-1}$; of maize were 5.4, 5.4, 5.1, and $5.1 \mathrm{mg} \mathrm{P} \mathrm{g}^{-1}$ for each treatment, respectively. We advertise to the readers that average grain $\mathrm{P}$ concentration may present interannual variability that was not taken into account because cultivars were not always the same. Spring wheat varieties used were provided from INTA EEA Paraná, soybean cultivars and maize hybrids used had similar agronomic characteristics and were from the same brands.

\section{Statistical Analysis}

Data collected were analyzed by ANOVA and treatment means were compared by the LSD test. Statistical analyses were performed with Infostat (Di Rienzo et al., 2011). The changes in soil P fractions with long-term $\mathrm{P}$ fertilization were calculated as the difference between the $\mathrm{P}$ fraction value in each treatment and the value of the same $\mathrm{P}$ fraction in the control treatment (no added $\mathrm{P}$ ) (expressed as percentage). These changes were calculated at $0-$ to $-5 \mathrm{~cm}$ and $0-$ to $-20 \mathrm{~cm}$ depth. Pearson correlation coefficients were determined for all soil (Bray1-P, Pt-CF, Po-CF, Pt-Bic, Po-

Bic, Pt-FF, and Po-FF data at 0- to-5 $\mathrm{cm}$ and 0- to $-20 \mathrm{~cm}$ depth) and crops variables (grain yield, relative yield, crop yield response, grain $\mathrm{P}$ concentration, and total $\mathrm{P}$ uptake for maize and soybean). Crops variables and only soil $\mathrm{P}$ fractions that increased the most with $\mathrm{P}$ fertilization and included organic $\mathrm{P}$ were considered in correlations. Relationships between accumulated apparent $\mathrm{P}$ budget and Bray1-P, Pt-CF, Po-CF, and Pt-Bic were evaluated by linear regressions for each soil. Comparisons between linear functions were made using an F test (Mead et al., 1993). For the Vertisol site, relationships between soybean grain yield and selected soil $\mathrm{P}$ fractions that increased with long-term $\mathrm{P}$ fertilization, and indices including organic and inorganic $\mathrm{P}$ were described by linear-plateau models fitted with Table Curve 5.0 (Systat Software Inc).

\section{Results}

\section{Soil P fractions}

After only one year, the initial P fertilization mainly increased inorganic P fractions (Table 2). Bray1-P significantly increased at both depths for both soils with P fertilization. Initial P 
fertilization did not significantly change Po-FF, Po-CF, and Po-Bic at both depths in the Mollisol and Vertisol, except Po-Bic at $0-$ to $-5 \mathrm{~cm}$ in the Vertisol. Total P in FF and Pt-Bic increased with $\mathrm{P}$ fertilization at both depths and soils. However, Pt-CF only increased in the Mollisol at 0- to -5 cm depth.

Long-term continuous $\mathrm{P}$ fertilization effect did not show an interaction between initial and annual P fertilization (Table 3 and 4), except for Po-CF at $0-$ to $-5 \mathrm{~cm}$ depth in the Mollisol (Table 3 ), and Pt-CF in the Vertisol at 0 - to $-20 \mathrm{~cm}$ depth (Table 4). Bray1-P concentration increased with annual P fertilization at both sampling depths in the Mollisol and the Vertisol (Table 3 and 4), and initial P fertilization only increased Bray1-P in the Mollisol at 0 - to $-20 \mathrm{~cm}$ depth (Table 3).

In the Mollisol, initial P fertilization did not affect any organic P fraction at both depths, but most organic $\mathrm{P}$ fractions significantly increased with annual $\mathrm{P}$ fertilization (Table 3 ). Total P fractions, including inorganic and organic $\mathrm{P}$, significantly increased with annual $\mathrm{P}$ fertilization at both depths, except Pt-FF at 0 - to $-5 \mathrm{~cm}$, while initial P fertilization only increased Pt-Bic. Instead, in the Vertisol, initial and annual $\mathrm{P}$ fertilization did not affect organic $\mathrm{P}$ fractions, except for PoBic that slightly increased at 0 - to $-5 \mathrm{~cm}$ depth (Table 4 ). Initial $\mathrm{P}$ fertilization only increased PtFF and Pt-CF at 0- to $-5 \mathrm{~cm}$ depth and Pt-CF at 0- to $-20 \mathrm{~cm}$ depth. However, annual $\mathrm{P}$ fertilization significantly increased total P fractions.

\section{Changes of P fractions due to long-term P fertilization}

Relative changes of soil $\mathrm{P}$ fractions showed that the three soil $\mathrm{P}$ fractions that increased the most at 0- to $-5 \mathrm{~cm}$ with P fertilization were Bray1-P, Pt-CF, and Pt-Bic in both soils (Figure 1). Similar results were observed at 0 - to $-20 \mathrm{~cm}$ depth. For the two sites, the relative change of $\mathrm{P}$ fractions was higher at 0 - to $-5 \mathrm{~cm}$ depth compared with 0 - to $-20 \mathrm{~cm}$ depth, and ranged between -7 to $89 \%$ and -13 to $266 \%$ in the Mollisol and the Vertisol sites, respectively. At $0-$ to $-20 \mathrm{~cm}$ depth, the relative change of $\mathrm{P}$ fractions varied from -9 to $110 \%$ in the Mollisol and from -25 to $179 \%$ in the Vertisol. Relative changes of $\mathrm{P}$ fractions due to $\mathrm{P}$ fertilization were higher in the Vertisol than in the Mollisol.

\section{Relationship between soil P fractions and crop variables}

Initial P fertilization treatments did not affect any measured variable for maize and soybean (Table

5). In contrast, annual $P$ fertilization increased shoot biomass and maize total $P$ uptake, and all measured variables for soybean. In the Mollisol, only at 0 - to $-20 \mathrm{~cm}$ depth Pt-CF was significantly correlated with grain yield response to P fertilization, and Po-CF with maize yield, 
grain yield response, and total P uptake. In the Vertisol, Bray1-P, Pt-FF, Pt-CF, Pt-Bic, and Po-Bic at 0 - to $-5 \mathrm{~cm}$ depth were significantly correlated with soybean grain yield, RY, grain P, and total $\mathrm{P}$ uptake. At 0- to $-20 \mathrm{~cm}$ depth, Bray1-P, Pt-CF, Po-CF, and Pt-Bic were correlated with soybean grain yield, RY, and grain P. Soybean grain yield response was only correlated with Pt-CF, whereas soybean total P uptake was significantly correlated with Bray1-P, Pt-CF, and Pt-Bic.

\section{Relationships between soil P fractions and accumulated apparent P budgets}

These relationships between $P$ fractions ( 0 - to $-20 \mathrm{~cm}$ depth) and grain yield, and accumulated apparent $\mathrm{P}$ budget were significant $(P<0.05)$ for all $\mathrm{P}$ fractions and sites, except for Po-CF (Figure 2), and the relationship between Pt-Bic and apparent $\mathrm{P}$ budget that showed different slopes and intercepts $(P<0.05)$ for each site. For the Mollisol site, slope and intercept were higher than those of the Vertisol site. Bray1-P also tended $(P=0,053)$ to be higher in the Mollisol than in the Vertisol site. In the relationships of accumulated apparent $\mathrm{P}$ budget with Pt-CF, the two sites did not differ in their slope $(P=0.12)$, but they significantly differed in their intercepts $(P<0.05)$. The common slope value for Pt-CF was $0.047 \mathrm{mg} \mathrm{P} \mathrm{kg}^{-1}$ soil per unit of change in apparent $\mathrm{P}$ budget.

When we compared accumulated apparent $\mathrm{P}$ budget relationship with soil $\mathrm{P}$ fractions within each site, for the Mollisol site, Bray1-P and Pt-CF showed no significant differences $(P>0.05)$ in their slopes, with a common slope of $0.041 \mathrm{mg} \mathrm{P} \mathrm{kg}^{-1}$ soil per unit of change in apparent $\mathrm{P}$ budget. In contrast, $\mathrm{Pt}$-Bic differed in its slope from the other fractions. The intercept for Pt-Bic was significantly different from Bray1-P and Pt-CF in the Mollisol site (Figure 2). For the Vertisol site, Bray1-P and Pt-Bic did not differ in their slope and intercepts. The common slope was $0.0147 \mathrm{mg} \mathrm{P} \mathrm{kg}^{-1}$ soil per unit of change in apparent P budget, and the intercept $7.9 \mathrm{mg}$ $\mathrm{P} \mathrm{kg}^{-1}$ soil. However, Pt-CF showed a higher slope and intercept than both, Bray1-P and Pt-Bic $(P<0.05)$. In spite of the relative changes of $\mathrm{P}$ fractions showed in Figure 1 were higher in the Vertisol than in the Mollisol, the Mollisol site presented a higher slope than the Vertisol for almost all P fractions. In the Vertisol, soil P fractions showed lower concentration than in the Mollisol site, therefore resulted in higher relative changes in Figure 1.

Soil P fractions ( 0 - to $-20 \mathrm{~cm}$ depth) that increased the most with long-term $\mathrm{P}$ fertilization for the Vertisol site were related to soybean grain yield (Figure 3). Maize grain yield did not increase with $\mathrm{P}$ fertilization in the Mollisol due to the initial soil $\mathrm{P}$ availability above critical levels. Among soil P fractions that increased the most with long-term P fertilization, Pt-Bic showed the highest coefficient of determination in its relationship with grain yield (Figure $3 b$ ). 
Organic P in CF performed similar than Pt-CF in its relationship with grain yield, and both had a higher coefficient of determination than Bray1-P, the current soil test P used in Argentina. When inorganic $\mathrm{P}$ fractions (Bray1-P and Pi-Bic) were combined with organic $\mathrm{P}$ fraction such us Po-CF better fit than other fractions alone were obtained (Figure $3 \mathrm{e}$ and $\mathrm{f}$ ).

\section{Discussion}

\section{Soil P fractions changes with long-term P fertilization}

The initial effect of $\mathrm{P}$ fertilization increased inorganic $\mathrm{P}$ fractions, but did not increase organic $\mathrm{P}$ fractions, probably because the organic matter was not a relevant short-term fate of fertilizer P. Therefore, increments in total $\mathrm{P}$ fractions were mainly determined by higher inorganic $\mathrm{P}$, as observed in experiments conducted in two types of soils. Organic P fractions would increase due to more input of fertilizer and recycling through crop residues in soils with a positive apparent $\mathrm{P}$ budget. Long-term $\mathrm{P}$ fertilization (9 $\mathrm{yr}$ of continuous $\mathrm{P}$ addition) increased total and inorganic $\mathrm{P}$ fractions, for initial and annual $\mathrm{P}$ fertilization in both sites, as it has been reported for similar $\mathrm{P}$ rates (Wyngaard et al., 2016). Another study reported that $\mathrm{P}$ fertilizer long-term applications increased all $\mathrm{P}$ fractions compared with continuous cropping without $\mathrm{P}$ fertilization (Negassa \& Leinweber, 2009). Here, the increases in inorganic $P$ with $P$ fertilization was up to 5 and 14 times higher than in organic P fraction for the Mollisol and the Vertisol sites, respectively.

Annual P fertilization increased all organic P fractions in the Mollisol, while in the Vertisol the Po-Bic was the only organic fraction showing a change at $0-5 \mathrm{~cm}$. Those differences between the Mollisol and the Vertisol could be due to native soil fertility (higher initial P values) of the Mollisol, as it was indicated in other studies (Ciampitti et al., 2011b). In addition, the differences could be related to higher productivity and crop residue inputs of crops in the Mollisol compared with the Vertisol which produced more organic P input and recycling. Novelli et al. (2017) showed that the Mollisol had higher productivity and crop residue input than the Vertisol. The effect of one high initial $\mathrm{P}$ fertilization rate did not increase organic $\mathrm{P}$ fractions in the Mollisol and the Vertisol measured after 9 years of continuous crop production because the accumulated apparent $\mathrm{P}$ budgets were slightly negative in the treatment with no annual $\mathrm{P}$ application.

Soil $\mathrm{P}$ fractions that increased the most with long-term $\mathrm{P}$ fertilization in this study agreed with previous results (Ciampitti et al., 2011b). In our study, when fractions that included organic plus inorganic labile $\mathrm{P}$ were considered (i.e. Pt-Bic and Pt-CF), we observed a similar or higher increase with P fertilization than in Bray1-P. Ciampitti et al. (2011b) reported that Pt-CF was a 
sensitive fraction to long-term fertilization in coarse-textured soils from the central Argentina Pampas Region. Therefore, Pt-CF showed changes under long-term $\mathrm{P}$ fertilization since it is a labile P fraction enriched by recycling of soil P through crops (Ha et al., 2008).

\section{Crops P nutrition}

Neither initial nor annual P fertilization affected maize crop growth and yield in the Mollisol, since soil Bray1-P of all treatments were above the critical level calibrated for maize in the Pampas Region (Sucunza et al., 2018). The lack of crop response to P addition, probably determined the lack of correlation between soil P fractions and maize crop variables. In contrast, soybean responses to $\mathrm{P}$ fertilization (grain yield, shoot biomass, grain $\mathrm{P}$, and total $\mathrm{P}$ uptake), was due to most soil Bray1-P values in the Vertisol were below the critical level at $0-$ to $-20 \mathrm{~cm}$ depth reported for Appelhans et al. (2016).

In the Vertisol, soybean crop variables showed a greater correlation with Pt-Bic than with Bray1-P. Although the previous report indicated a significant correlation between Pi-Bic with soybean yield and relative yield, a relationship that increased when included organic $\mathrm{P}$ and considered Pt-Bic, it was not recommended as a better option to the most used soil test $\mathrm{P}$ (Appelhans et al., 2016). These results brought out that organic P contributed to P nutrition and improved the relationship with P uptake. Furthermore, Ciampitti et al. (2011b) showed similar results, reporting that $\mathrm{Pt}-\mathrm{CF}$ was related to maize $\mathrm{P}$ uptake up to flowering, in agreement with our results for soybean.

The relationship between accumulated apparent $\mathrm{P}$ budget and Bray1-P, Pt-Bic, and Pt-CF in the Mollisol and the Vertisol site differed in their intercepts, as this parameter depends on the initial soil P content (Ciampitti et al., 2011a; Dodd \& Mallarino, 2005). In the Vertisol site, the slope of the relationship between Pt-Bic and Bray1-P with apparent P budget indicated a greater change in apparent $\mathrm{P}$ budget required to increase Pt-Bic and Bray1-P values than in the Mollisol. The Vertisol has greater clay content and $\mathrm{P}$ adsorption capacity (Quintero et al., 2003), so more $\mathrm{P}$ is needed to increase Pt-Bic compared with the Mollisol. In addition, the Vertisol site had a less productive and intensive crop sequence (Novelli et al., 2017).

Contrasting results were observed in the relationship between Pt-CF and accumulated apparent P budget, where a common slope was observed for both sites. Differences between sites were not observed when $\mathrm{P}$ was measured in a coarse soil fraction ( $>53 \mathrm{um})$, which excludes the clay content differences between soils, where P added could be sorbed. In the Vertisol, Pt-CF 
showed a higher relative change (2.8 times respect to control treatment) compared to the other fractions (2.5 and 2.2 times respect to control treatment for Bray1-P and Pt-Bic, respectively). Therefore, similar changes in Pt-CF were obtained with similar accumulated apparent $\mathrm{P}$ budgets in fertilized treatments in the Mollisol and the Vertisol site, due to CF is a fraction composed by plant residues that are partially decomposed and sand (Ha et al., 2008), and it is more related to crop residue production and recycling.

Although total P uptake correlated similarly to Bray1-P, Pt-Bic, and Pt-CF, the extractable soil $\mathrm{P}$ concentration is not the only factor controlling plant $\mathrm{P}$ uptake (Barber, 1980; Fixen \& Grove, 1990). Furthermore, there are several factors influencing crop P nutrition and its impact on grain yield (Beegle, 2005), thus a similar correlation between Bray1-P, Pt-Bic, and Pt-CF with total P uptake does not imply a similar relationship with grain yield.

Total $\mathrm{P}$ in $\mathrm{NaHCO}_{3}$ extracts had a closer relationship with soybean grain yield than Bray1$\mathrm{P}$ in the Vertisol (Figure 3b), suggesting that Pt-Bic could be considered for the development of improved diagnostic methods of $\mathrm{P}$ fertility in Vertisols. For that reason, in soils with low Bray1-P levels, available P would be replenished by soil P fractions not accounted for Bray1-P (Sucunza et al., 2018). Therefore, in the Vertisol, a greater proportion of crop P uptake could be supplied by labile inorganic and organic $\mathrm{P}$ fractions, such as Pt-Bic, which could be a more accurate index to asses $\mathrm{P}$ availability that would replenish available $\mathrm{P}$ for soybean.

Likewise, total and organic P in CF were better related to soybean yield than Bray1-P, but these results did not agree with our previous study. Appelhans et al. (2016) showed that Pt-CF was not related to soybean yield response to $\mathrm{P}$ fertilization, including soils with a wide range of variation on different $\mathrm{P}$ fractions, contrasting texture, different preceding crops, and environmental conditions during the cropping season. Even though Po-CF was suggested as an index useful to predict potential organic P mineralization (Wyngaard et al., 2016), and sensitive to crop management practices including long-term $\mathrm{P}$ fertilization, this soil $\mathrm{P}$ fraction was not correlated with soybean total P uptake. However, it showed a higher fit with soybean grain yield than Bray1$\mathrm{P}$. Mineralization of organic $\mathrm{P}$ fractions during the growing season was expected to be an important, but not the only source of available $\mathrm{P}$ to soybean. Labile inorganic $\mathrm{P}$ is another important source of available P for a crop (Sharpley, 1995).

In order to account for both $\mathrm{P}$ sources, we propose an index of $\mathrm{P}$ availability adding labile $\mathrm{Po}+\mathrm{Pi}$. These two indices (Bray1-P $+\mathrm{Po}-\mathrm{CF}$, and Pi-Bic + Po-CF) showed a close relationship with soybean yield in the Vertisol and highlighted the importance of considering both, organic and 
inorganic available $\mathrm{P}$ sources for crops in a soil test $\mathrm{P}$. However, total $\mathrm{P}$ determinations, required to calculate Po-CF, will be more time-consuming, laborious, and increase soil test cost. In this way, more effort should be focused on developing a simple methodology to determine a soil test P including inorganic and labile organic $\mathrm{P}$ in a single step.

\section{Conclusions}

Greater changes in soil P fractions with long-term P fertilization were measured in Bray1-P, PtBic, and Pt-CF for the Mollisol and theVertisol site. These fractions were similarly related to grain $\mathrm{P}$ and total $\mathrm{P}$ uptake in the Vertisol. Greater apparent $\mathrm{P}$ budget was required in the Vertisol to increased Pt-Bic and Bray1-P values than in the Mollisol, but a common slope in the relationship between Pt-CF with accumulated apparent P budget was observed for both soils.

Total $\mathrm{P}$ in $\mathrm{NaHCO}_{3}$ extract and Pt-CF and Po-CF were better related to soybean grain yield than Bray1-P. Proposed P indices that included labile inorganic and organic P, such us Bray1-P + Po-CF and Pi-Bic + Po-CF, showed a strong relationship with soybean grain yield in the Vertisol site and were an integrated approach to evaluate soil $\mathrm{P}$ availability. Phosphorus fractions that included labile organic $\mathrm{P}$ showed promising results for improving the diagnosis of $\mathrm{P}$ soil fertility in summer crops as they measured both available P sources for crops such as inorganic and organic P.

\section{Acknowledgments}

Financial support provided by INTA PNSUELO-1134024, PNCYO 1127033, ERIOS-1263101, and ERIOS-1263102. Stefania Appelhans holds a scholarship of CONICET. We thank Eliana Bressan for her assistance in the laboratory and for the help in the field.

\section{References}

Appelhans, S.C., Melchiori, R.J., Barbagelata, P. A., \& Novelli, L.E. (2016). Assessing organic phosphorus contributions for predicting soybean response to fertilization. Soil Sci. Soc. Am. J. 80: 1688-1697. doi:10.2136/sssaj2016.04.0130

Barber, S.A. (1980). Soil-plant interactions in the phosphorus nutrition of plants. In: Khasawneh, F.E., Sample, E.C., \&. Kamprath, E.J., editors, The role of phosphorus in agriculture. ASA., Madison, WI. p. 591-615 
Beegle, D. (2005). Assessing soil phosphorus for crop production by soil testing. In: Sims, J.T., \& Sharpley, A.N., editors, Phosphorus: Agriculture and the Environment, Agron. Monogr. 46. ASA, CSSA, SSSA, Madison, WI. p. 123-143.

Boschetti, N.G., Quinteros, C.E., Benavidez, R.A., \& Giuffre, L. (2003). Cuantificación de las fracciones orgánicas e inorgánicas de fósforo en suelos de la Mesopotamia argentina. Cienc. Suelo 21:1-8.

Bray, R.H., \& Kurtz, L.T. (1945). Determination of total, organic, and available forms of phosphorus in soil. Soil Sci. 59:39-45.

Cambardella, C.A., \& Elliott, E.T. (1992). Particulate soil organic-matter changes across a grassland cultivation sequence. Soil Sci. Soc. Am. J. 56:777-783. doi:10.2136/sssaj1992.03615995005600030017x

Caviglia, O.P., Rizzallid, R.H., Monzon, J.P., García, F.O., Melchiori, R.J.M., Martinez, J.J., Cerrudo, A., Irigoyen, A., Barbieri, P.A., Van Opstal, N.V. \& Andrade, F.H. 2019. Improving resource productivity at a crop sequence level. Field Crops Res 235:129-141

Ciampitti, I.A., Garcia, F.O., Picone, L.I., \& Rubio, G. (2011a). Phosphorus budget and soil extractable dynamics in field crop rotations in Mollisols. Soil Sci. Soc. Am. J. 75:131-142. doi:10.2136/sssaj2009.0345

Ciampitti, I.A., Garcia, F.O., Picone, L.I., \& Rubio, G. (2011b). Soil carbon and phosphorus pools in field crop rotations in Pampean soil of Argentina. Soil Sci. Soc. Am. J 75:616-625. doi:10.2136/sssaj2010.0168

Condron, L.M., Turner, B.L., \& Cade-Menun, J. (2005). Chemistry and dynamics of soil organic phosphorus. In: Sims, J.T., \& Sharpley, A.N., editors, Phosphorus: Agriculture and the Environment, Am. Soc. Agr., Madison, WI. p. 87-121.

Di Rienzo, J.A., Casanoves, F., Balzarini, M.G., Gonzalez, L., Tablada, M., \& Robledo, C.W. (2011). InfoStat versión 2011. Grupo InfoStat, FCA, Universidad Nacional de Córdoba, Argentina.

Dodd, R. J., \& Mallarino, A. (2005). Soil-test phosphorus and crop grain yield responses to longterm phosphorus fertilization for corn-soybean rotations. Soil Sci. Soc. Am. J. 69:1118-1128. doi:10.2136/sssaj2004.0279

Dodd, R.J., \& Sharpley, A.N. (2015). Recognizing the role of soil organic phosphorus in soil fertility and water quality. Resources, Conservation and Recycling. 105 B: 282-293. https://doi.org/10.1016/j.resconrec.2015.10.001 
Fixen, P, \& Grove, J.H. (1990). Testing soils for phosphorus. In: Westerman, R.L., editor, Soil testing and plant analysis. 3rd ed. Soil Sci. Soc. Am. Book Series, Madison. p 141-180

Gee, G.W., \& Bauder, J.W. (1986). Particle-size analysis. In: Klute, A., editor, Methods of soil analysis: Physical and mineralogical methods. Agron. Monogr. 9. 2nd ed. ASA, Madison, WI. p. 383-411.

Ha, K.V., Marschner, P., \& Bünemann, E.K. (2008). Dynamics of C, N, P and microbial community composition in particulate soil organic matter during residue decomposition. Plant Soil 303:253-264.

Hedley, M.J., Stewart, J.W.B., \& Chahuan, B.S. (1982). Changes in inorganic and organic soil phosphorus fractions induced by cultivation practices and by laboratory incubations. Soil Sci. Soc. Am. J. 46: 970-976. doi:10.2136/sssaj1982.03615995004600050017x

Irizar, A., Andriulo, A., Consentino, D., \& Amendola, C. (2010). Comparación de dos métodos de fraccionamiento físico de la materia orgánica del suelo. Cienc. Suelo 28: 115-121.

Kuo, S. (1990). Phosphorus. In: Methods of Soil Analysis. Part 3. Chemical Methods. Soil Sci. Soc. Am. Book Serie 5. Madison, WI. p. 869-919.

McDowell, R.W., Condron, L. M., \& Stewart, I. (2008). An examination of potential extraction methods to assess plant-available organic phosphorus in soil. Soil Biology and Fertility of Soils. 44: 707-715.

Mead, R., Curnow, R.N., \& Hasted, A.M. (1993). Statistical methods in agriculture and experimental biology. Chapman and Hall, London.

Negassa, W., \& Leinweber, P. 2009. How does the Hedley sequential phosphorus fractionation reflect impacts of land use and management on soil phosphorus: a review. J. Plant Nutr. Soil Sci. 172:305-325.

Novelli, L.E., Caviglia, O.P., \& Piñeiro, G. (2017). Increased cropping intensity improves crop residue inputs to the soil and aggregate-associated soil organic carbon stocks. Soil Till. Res. 165:128-136. https://doi.org/10.1016/j.still.2016.08.008

Quintero, C. E., Boschetti, N.G., \& Benavidez, R.A. (2003). Effect of Soil Buffer Capacity on Soil Test Phosphorus Interpretation and Fertilizer Requirement. Communications in Soil Science and Plant Analysis 34:1435-1450.

Rocha, J.H.T., Menegale, M.L.C., Rodrigues, M., Goncalves, J.L.M., Pavinato, P.S., Foltran, E.C., Harrison, R., \& James, J.N. 2019. Impacts of timber harvest intensity and P fertilizer application on soil P fractions. For. Ecol. Manage. 437:295-303. 
Rodrigues, M., Pavinato, P.S., \& Withers, P.J.A. 2016. Legacy phosphorus and no-tillage agriculture in tropical oxisols of the Brazilian savanna. Sci. Total Environ. 542:1050-1061.

Sharpley, A.N. (1995). Soil phosphorus dynamics: Agronomic and environmental impacts. Ecol. Eng. 5:261-279. https://doi.org/10.1016/0925-8574(95)00027-5

Soil Survey Staff. (2014). Soil Survey Field and Laboratory Methods Manual. Soil Survey Investigations Report 51, Version 2.0. R. Burt, and Soil Survey Staff, editors, Washington, Department of Agriculture, Natural Resources Conservation Service

Steffens, D., Leppin, T., Luschin-Ebengreuth, N., Yang, Z., \& Schubert, S. (2010). Organic soil phosphorus considerably contributes to plant nutrition but is neglected by routine soil-testing methods. J. Plant Nutr. Soil Sci. 173: 765-771. https://doi.org/10.1002/jpln.201000079

Stewart, J., \& Sharpley, A. (1987). Controls on dynamics of soil and fertilizer phosphorus and sulfur. In: Follet, R., Stewart, J., \& Cole, C., editors, Soil fertility and organic matter as critical components of production systems. SSSA Spec. Pub. 19. SSSA-ASA. Madison, WI. p. 101-121.

Sucunza, F. A., Gutierrez Boem, F.H., Garcia, F.O., Boxler, M., \& Rubio, G. (2018). Long-term phosphorus fertilization of wheat, soybean and maize on Mollisols: soil test trends, critical levels and balances. European Journal of Agronomy 96:87-95. https://doi.org/10.1016/j.eja.2018.03.004

Thien, S.J., \& Myers, R. (1992). Determination of bioavailable phosphorus in soil. Soil Sci. Soc. Am. J. 56:814-818. doi:10.2136/sssaj1992.03615995005600030023x

Tiessen, H., Stewart, J.W.B., \& Oberson, A. (1994). Innovative soil phosphorus availability indices. Assessing organic phosphorus. In: Havlin, J.L., \& Jacobsen, J.S., editors, Soil testing: prospects for improving nutrient recommendations. Soil Sci. Soc. Am. Spec. 40, Madison, WI. p. 143-162.

Van Lierop, W. (1990). Soil pH and lime requirements determination. In: Westerman, R.L., editor, Soil testing and plant analysis. 3er ed. SSSA Book Ser. 3. SSSA, Madison, WI. p. 73-126.

Walkley, A., \& Black, I.A. (1934). An examination of the Degtjareff method for determining soil organic matter, and a proposed modification of the chromic acid titration method. Soil Sci. 37: 29-38.

Wyngaard, N., Vidaurreta, A., Echeverria, H.E., \& Picone, L.I. (2013). Dynamics of phosphorus and carbon in the soil particulate fraction under different management practices. Soil Sci. Soc. Am. J. 77:1584-1590. doi:10.2136/sssaj2013.04.0137 
Wyngaard, N., Cabrera, M. L., Jarosch, K.A., \& Bünemann, E.K. (2016). Phosphorus in the coarse soil fraction is related to soil organic phosphorus mineralization measured by isotopic dilution. Soil Biol. Biochem. 96:107-118. https://doi.org/10.1016/j.soilbio.2016.01.022 


\section{FIGURE CAPTIONS}

Figure 1. Percentage of change of each treatment respect to control treatment (no added $\mathrm{P})$ after 9 years of annual $\mathrm{P}$ application of Bray1-P, total $\mathrm{P}$ in fine soil fraction(FF) (Pt$\mathrm{FF}$ ), inorganic $\mathrm{P}$ in $\mathrm{FF}$, organic $\mathrm{P}$ in $\mathrm{FF}$, total $\mathrm{P}$ in coarse soil fraction $(\mathrm{CF})(\mathrm{Pt}-\mathrm{CF})$, inorganic $\mathrm{P}$ in $\mathrm{CF}$, organic $\mathrm{P}$ in $\mathrm{CF}$, total $\mathrm{P}(\mathrm{Pt}-\mathrm{Bic})$, and organic $\mathrm{P}(\mathrm{Po}-\mathrm{Bic})$ in $\mathrm{NaHCO}_{3}$ extract for: a) Mollisol at 0- to $-5 \mathrm{~cm}$ depth, b) Vertisol at 0- to $-5 \mathrm{~cm}$ depth, c) Mollisol at 0 - to $-20 \mathrm{~cm}$ depth, and d) Vertisol at $0-$ to $-20 \mathrm{~cm}$ depth.

Figure 2. Relationships between accumulated apparent $\mathrm{P}$ budget of 9 years (fertilizer applied $\mathrm{P}$ - crops grain $\mathrm{P}$ uptake) $\left(\mathrm{kg} \mathrm{ha}^{-1}\right)$ and: a) Bray1-P $\left(\mathrm{mg} \mathrm{kg}^{-1}\right)$, b) total $\mathrm{P}$ in $\mathrm{NaHCO}_{3}$ extract $\left.(\mathrm{Pt}-\mathrm{Bic})\left(\mathrm{mg} \mathrm{kg}^{-1}\right), \mathrm{c}\right)$ total $\mathrm{P}$ in the coarse fraction $(\mathrm{CF})(\mathrm{Pt}-\mathrm{CF})(\mathrm{mg}$ $\left.\mathrm{kg}^{-1}\right)$, and d) organic $\mathrm{P}$ in $\mathrm{CF}(\mathrm{Po}-\mathrm{CF})\left(\mathrm{mg} \mathrm{kg}^{-1}\right)$ at 0 - to $-20 \mathrm{~cm}$ soil sampling depth. Circles are for the Mollisol site and triangles for the Vertisol site.

Figure 3. Relationships between soybean grain yield and selected $\mathrm{P}$ fractions at 0 - to $20 \mathrm{~cm}$ soil depth in the Vertisol: a) Bray1-P $\left(\mathrm{mg} \mathrm{kg}^{-1}\right)$, b) total $\mathrm{P}$ in $\mathrm{NaHCO}_{3}$ extract (Pt-Bic) $\left.\left(\mathrm{mg} \mathrm{kg}^{-1}\right), \mathrm{c}\right)$ total $\mathrm{P}$ in coarse fraction $\left.(\mathrm{CF})(\mathrm{Pt}-\mathrm{CF})\left(\mathrm{mg} \mathrm{kg}^{-1}\right), \mathrm{d}\right)$ organic $\mathrm{P}$ in $\mathrm{CF}(\mathrm{Po}-\mathrm{CF})\left(\mathrm{mg} \mathrm{kg}^{-1}\right)$, e) Bray1-P plus Po-CF $\left(\mathrm{mg} \mathrm{kg}^{-1}\right)$, and f) inorganic $\mathrm{P}$ in $\mathrm{NaHCO}_{3}$ extract (Pi-Bic) plus Po-CF $\left(\mathrm{mg} \mathrm{kg}^{-1}\right)$. All fitted relationships were statistically significant $(P<0.05)$. 


\section{TABLES}

Table 1. Soil characteristics of the Mollisol and Vertisol sites at the beginning of the experiments $(0-20 \mathrm{~cm}$ depth).

\begin{tabular}{ccccccc} 
Soil & $\mathrm{pH}$ & clay & $\begin{array}{c}\text { silt } \\
\ldots \ldots \ldots \ldots \ldots \ldots \ldots \ldots\end{array}$ & sand & $\begin{array}{c}\text { SOC } \\
\mathrm{g} \mathrm{kg}^{-1}\end{array}$ & $\begin{array}{c}\text { Bray 1 P } \\
\mathrm{mg} \mathrm{kg}^{-1}\end{array}$ \\
\hline Mollisol & 6.3 & 32.4 & 65.7 & 1.9 & 15.9 & 21.1 \\
Vertisol & 7.4 & 42.8 & 51.6 & 5.6 & 20.3 & 7.2 \\
\hline
\end{tabular}


Table 2.Effect of initial $\mathrm{P}$ fertilization after one year of $\mathrm{P}$ application at $0-$ to $-5 \mathrm{~cm}$ and 0 - to $-20 \mathrm{~cm}$ soil depth on Bray $1-\mathrm{P}$, total, inorganic, and organic $\mathrm{P}$ in fine fraction (FF) (Pt-FF, Pi-FF, and Po-FF, respectively) and coarse fraction (CF) (Pt-CF, Pi-CF, and Po-CF, respectively), and in $\mathrm{NaHCO}_{3}$ extract (Pt-Bic, Pi-Bic, and Po-Bic, respectively). Soil samples from 2008 for Mollisol, and 2007 for Vertisol.

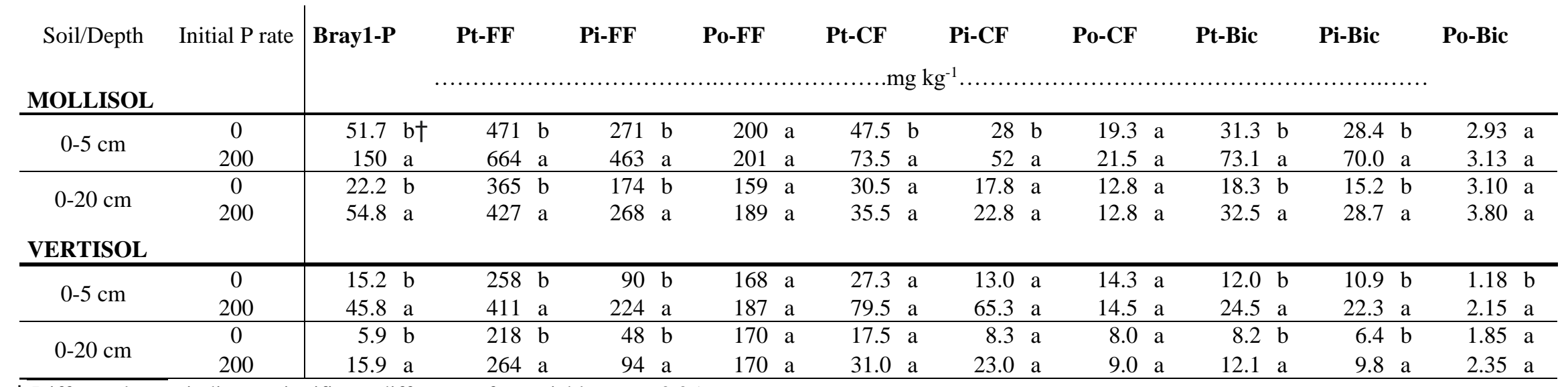

† Different letters indicates significant differences for variables at $P<0.05$. 
Table 3. Accumulated effect of initial and annual $P$ fertilization in the Mollisol 9 years after the beginning of the experiment (2016) at 0 - to $-5 \mathrm{~cm}$ and 0- to -20 cm soil depth on Bray1-P, total, inorganic, and organic P in fine fraction (FF) (Pt-FF, Pi-FF, and Po-FF, respectively) and coarse fraction (CF) (Pt-CF, Pi-CF, and Po-CF, respectively), and in $\mathrm{NaHCO}_{3}$ extract (Pt-Bic, Pi-Bic, and Po-Bic, respectively).

\begin{tabular}{|c|c|c|c|c|c|c|c|c|c|c|c|c|}
\hline Depth & Main effect & $\begin{array}{c}\text { Rate } \\
\mathrm{kg} \mathrm{ha}^{-1}\end{array}$ & Bray1-P & Pt -FF & Pi-FF & Po-FF & Pt -CF & $\mathrm{Pi}-\mathrm{CF}$ & Po-CF & Pt -Bic & Pi-Bic & Po-Bic \\
\hline \multirow{4}{*}{$0-5 \mathrm{~cm}$} & \multirow{2}{*}{$\begin{array}{c}\text { Initial P } \\
\text { fertilization }\end{array}$} & 0 & $57.0 \mathrm{a} \dagger$ & 562 a & $302 \mathrm{~b}$ & 249 a & $60.0 \mathrm{a}$ & $32.0 \mathrm{a}$ & $22.2 \mathrm{c}$ & $31.4 \mathrm{~b}$ & $28.1 \mathrm{~b}$ & $2.9 \mathrm{a}$ \\
\hline & & 200 & 74.9 a & 582 a & $387 \mathrm{a}$ & $281 \mathrm{a}$ & $67.2 \mathrm{a}$ & $39.3 \mathrm{a}$ & 33.8 a & $41.8 \mathrm{a}$ & 38.9 a & $3.3 \mathrm{a}$ \\
\hline & \multirow{2}{*}{$\begin{array}{c}\text { Annual P } \\
\text { fertilization }\end{array}$} & 0 & $55.1 \mathrm{~b}$ & 565 a & 299 a & $263 \mathrm{a}$ & $48.5 \mathrm{~b}$ & $24.1 \mathrm{~b}$ & 26.7 bc & $30.7 \mathrm{~b}$ & $28.5 \mathrm{a}$ & $2.2 \mathrm{~b}$ \\
\hline & & 36 & $76.9 \mathrm{a}$ & $580 \quad \mathrm{a}$ & $389 \mathrm{a}$ & $267 \mathrm{a}$ & $78.7 \mathrm{a}$ & $47.2 \mathrm{a}$ & $29.3 \mathbf{a b}$ & $42.5 \mathrm{a}$ & 38.5 a & $4.0 \mathrm{a}$ \\
\hline \multirow{4}{*}{$\begin{array}{c}0-20 \\
\mathrm{~cm}\end{array}$} & \multirow{2}{*}{$\begin{array}{l}\text { Initial P } \\
\text { fertilization }\end{array}$} & 0 & $25.3 \mathrm{~b}$ & $420 \mathrm{a}$ & $201 \mathrm{~b}$ & $219 \mathrm{a}$ & $28.3 \mathrm{a}$ & $16.1 \mathrm{a}$ & $12.3 \mathrm{a}$ & $15.0 \mathrm{~b}$ & $12.7 \mathrm{~b}$ & $2.2 \mathrm{a}$ \\
\hline & & 200 & $34.9 \mathrm{a}$ & $472 \mathrm{a}$ & $237 \mathrm{a}$ & $235 \mathrm{a}$ & $32.5 \mathrm{a}$ & $19.6 \mathrm{a}$ & $14.1 \mathrm{a}$ & $21.0 \mathrm{a}$ & $18.8 \mathrm{a}$ & $2.3 \mathrm{a}$ \\
\hline & \multirow{2}{*}{$\begin{array}{c}\text { Annual P } \\
\text { fertilization }\end{array}$} & 0 & $24.5 \mathrm{~b}$ & $418 \mathrm{~b}$ & $199 \mathrm{~b}$ & $219 \mathrm{~b}$ & $24.2 \mathrm{~b}$ & $13.3 \mathrm{~b}$ & $11.0 \mathrm{~b}$ & $14.5 \mathrm{~b}$ & $12.8 \mathrm{~b}$ & $1.7 \mathrm{~b}$ \\
\hline & & 36 & $35.7 \mathrm{a}$ & $474 \mathrm{a}$ & 239 a & $235 \mathrm{a}$ & $36.6 \mathrm{a}$ & $22.4 \mathrm{a}$ & $15.4 \mathrm{a}$ & $21.5 \mathrm{a}$ & $18.6 \mathrm{a}$ & $2.8 \mathrm{a}$ \\
\hline
\end{tabular}

$\uparrow$ Different letters indicate significant main effect for initial P fertilization or annual P fertilization, and bold letters refer to significant differences (LSD test, $P<0.05)$ for

variables that showed initial $\mathrm{P}$ fertilization and annual $\mathrm{P}$ fertilization interaction. 
Table 4. Accumulated effect of initial and annual $P$ fertilization in the Vertisol 9 years after the beginning of the experiment (2016) at 0 - to $-5 \mathrm{~cm}$ and 0- to -20 cm soil depth on Bray1-P, total, inorganic, and organic P in fine fraction (FF) (Pt-FF, Pi-FF, and Po-FF, respectively) and coarse fraction (CF) (Pt-CF, Pi-CF, and Po-CF, respectively), and in $\mathrm{NaHCO}_{3}$ extract (Pt-Bic, Pi-Bic, and Po-Bic, respectively).

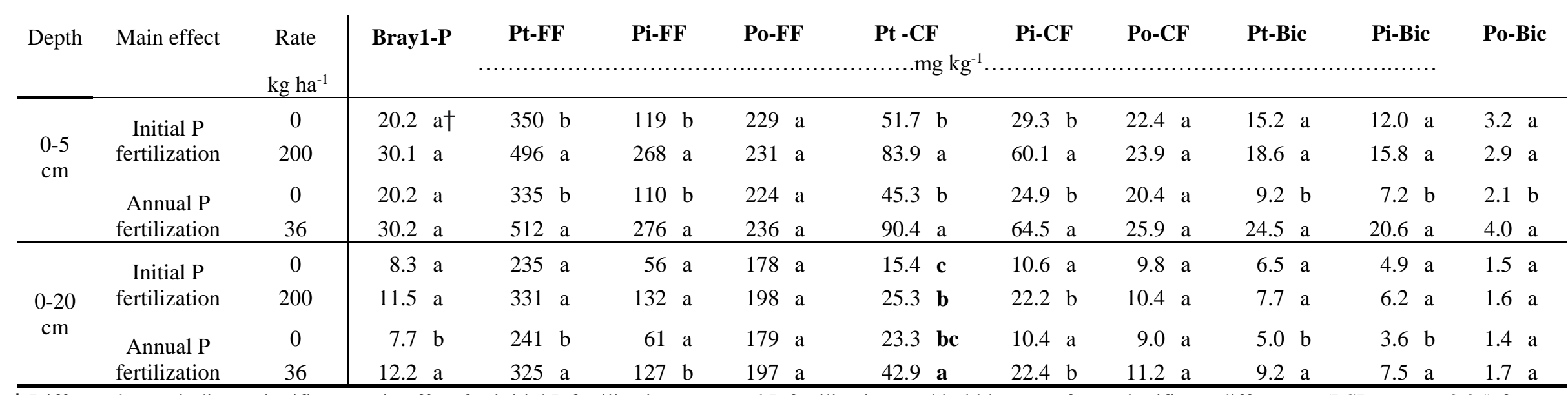

$†$ Different letters indicate significant main effect for initial P fertilization or annual P fertilization, and bold letters refer to significant differences (LSD test, $P<0.05$ ) for

variables that showed initial $\mathrm{P}$ fertilization and annual $\mathrm{P}$ fertilization interaction. 
Table 5. Effect of $P$ fertilization treatments on maize and soybean grain yield, shoot biomass (Biomass), grain $P$ concentration (Grain $P$ ), and total P uptake. Maize and soybean as single crops in 2016 cropping season.

\begin{tabular}{|c|c|c|c|c|c|c|c|}
\hline $\begin{array}{l}\text { Crop } \\
\& \text { Soil }\end{array}$ & Main effect & $\begin{array}{c}\text { Rate } \\
\mathrm{kg} \mathrm{ha}^{-1}\end{array}$ & $\begin{array}{r}\text { Yield } \\
\mathrm{kg} \mathrm{ha}^{-1} \\
\end{array}$ & $\begin{array}{r}\text { Biomass } \\
\mathrm{kg} \mathrm{ha}^{-1}\end{array}$ & & $\begin{array}{c}\text { Grain P } \\
\mathrm{mg} \mathrm{g}^{-1}\end{array}$ & $\begin{array}{c}\text { Total P uptake } \\
\text { kg P ha }\end{array}$ \\
\hline \multirow{4}{*}{$\begin{array}{l}\text { Maize } \\
\text { Mollisol }\end{array}$} & \multirow{2}{*}{$\begin{array}{c}\text { Initial P } \\
\text { fertilization }\end{array}$} & 0 & 11773 a† & 20422 & $\mathrm{a}$ & $4.1 \mathrm{a}$ & $51.5 \mathrm{a}$ \\
\hline & & 200 & 11971 a & 22383 & $\mathrm{a}$ & $4.4 \mathrm{a}$ & $52.2 \mathrm{a}$ \\
\hline & \multirow{2}{*}{$\begin{array}{c}\text { Annual P } \\
\text { fertilization } \\
\end{array}$} & 0 & 11653 a & 19603 & $\mathrm{~b}$ & $4.1 \mathrm{a}$ & $46.5 \mathrm{~b}$ \\
\hline & & 36 & $12091 \mathrm{a}$ & 23202 & $\mathrm{a}$ & $4.4 \mathrm{a}$ & $57.2 \mathrm{a}$ \\
\hline \multirow{4}{*}{$\begin{array}{l}\text { Soybean } \\
\text { Vertisol }\end{array}$} & \multirow{2}{*}{$\begin{array}{c}\text { Initial P } \\
\text { fertilization }\end{array}$} & 0 & 3344 a & 7323 & $\mathrm{a}$ & $4.2 \mathrm{a}$ & $17.7 \mathrm{a}$ \\
\hline & & 200 & 3672 a & 8738 & $\mathrm{a}$ & $4.7 \mathrm{a}$ & $22.4 \mathrm{a}$ \\
\hline & \multirow{2}{*}{$\begin{array}{c}\text { Annual P } \\
\text { fertilization }\end{array}$} & 0 & $2810 \mathrm{~b}$ & 6877 & $\mathrm{~b}$ & $3.8 \mathrm{~b}$ & $13.8 \mathrm{~b}$ \\
\hline & & 36 & $4206 \mathrm{a}$ & 9185 & $\mathrm{a}$ & $5.1 \mathrm{a}$ & $25.8 \mathrm{a}$ \\
\hline
\end{tabular}

† Different letters indicate a significant main effect for initial P fertilization or annual P fertilization (LSD test, $P<0.05)$. 
Table 6 Pearson correlation coefficients between soil P fractions and crop response variables after 9 years of annual P application: yield, relative yield (RY), grain yield response (Response), grain P concentration (grain P), and total $\mathrm{P}$ uptake for maize and soybean at 0 - to-5 $\mathrm{cm}$ and 0 - to -20 cm depth.

\begin{tabular}{|c|c|c|c|c|c|c|c|c|c|c|}
\hline \multirow[b]{2}{*}{$0-5 \mathrm{~cm}$} & \multicolumn{5}{|c|}{ Maize (Mollisol) } & \multicolumn{5}{|c|}{ Soybean (Vertisol) } \\
\hline & Yield & RY & Response & Grain P & $\begin{array}{l}\text { Total P } \\
\text { uptake }\end{array}$ & Yield & $\mathrm{RY}$ & Response & Grain $\mathrm{P}$ & $\begin{array}{l}\text { Total P } \\
\text { uptake }\end{array}$ \\
\hline Bray1-P & -0.40 & -0.42 & -0.22 & 0.11 & 0.03 & 0.57 & 0.57 & 0.25 & 0.58 & 0.65 \\
\hline $\mathrm{Pt}-\mathrm{FF}$ & 0.05 & 0.22 & 0.1 & -0.14 & 0.24 & 0.69 & 0.62 & 0.62 & 0.73 & 0.65 \\
\hline Po-FF & 0.07 & -0.19 & -0.13 & -0.34 & 0.11 & 0.15 & 0.18 & 0.42 & 0.12 & 0.08 \\
\hline $\mathrm{Pt}-\mathrm{CF}$ & 0.12 & 0.11 & 0.23 & 0.14 & 0.39 & 0.67 & 0.61 & 0.71 & 0.65 & 0.68 \\
\hline Po-CF & 0.02 & -0.03 & 0.15 & 0.36 & 0.4 & 0.39 & 0.39 & -0.05 & 0.27 & 0.25 \\
\hline Pt-Bic & -0.04 & 0.45 & 0.14 & 0.02 & 0.24 & 0.78 & 0.79 & 0.48 & 0.73 & 0.75 \\
\hline $\begin{array}{l}\text { Po-Bic } \\
\mathbf{0 - 2 0} \mathbf{~ c m}\end{array}$ & 0.13 & -0.13 & 0.18 & 0.14 & 0.46 & 0.61 & 0.66 & 0.31 & 0.57 & 0.53 \\
\hline Bray1-P & -0.29 & -0.32 & -0.16 & 0.04 & 0.09 & 0.60 & 0.60 & 0.31 & 0.63 & 0.63 \\
\hline Pt-FF & 0.25 & 0.03 & 0.27 & 0.04 & 0.33 & 0.45 & 0.36 & 0.24 & 0.51 & 0.26 \\
\hline Po-FF & 0.38 & -0.19 & 0.21 & -0.03 & 0.32 & 0.42 & 0.32 & 0.23 & 0.39 & 0.09 \\
\hline $\mathrm{Pt}-\mathrm{CF}$ & 0.39 & 0.21 & 0.50 & 0.31 & 0.25 & 0.61 & 0.53 & 0.64 & 0.64 & 0.58 \\
\hline Po-CF & 0.64 & 0.18 & 0.65 & 0.42 & 0.52 & 0.60 & 0.56 & 0.14 & 0.55 & 0.36 \\
\hline Pt-Bic & -0.05 & 0.29 & 0.11 & $4.00 \mathrm{E}-04$ & 0.47 & 0.66 & 0.65 & 0.39 & 0.64 & 0.63 \\
\hline Po-Bic & 0.36 & 0.06 & 0.39 & 0.04 & 0.36 & 0.14 & 0.11 & 0.08 & 0.15 & 0.13 \\
\hline
\end{tabular}

Significant relationships $(P<0.05)$ are in bold. References: total, inorganic, and organic $\mathrm{P}$ in fine $(\mathrm{FF})(\mathrm{Pt}-\mathrm{FF}$, Pi-FF, and Po-FF, respectively) and coarse soil fractions $(\mathrm{CF})(\mathrm{Pt}-$

$\mathrm{CF}$, Pi-CF, and Po-CF, respectively), and in $\mathrm{NaHCO}_{3}$ extract (Pt-Bic, Pi-Bic, and Po-Bic, respectively). 
a)
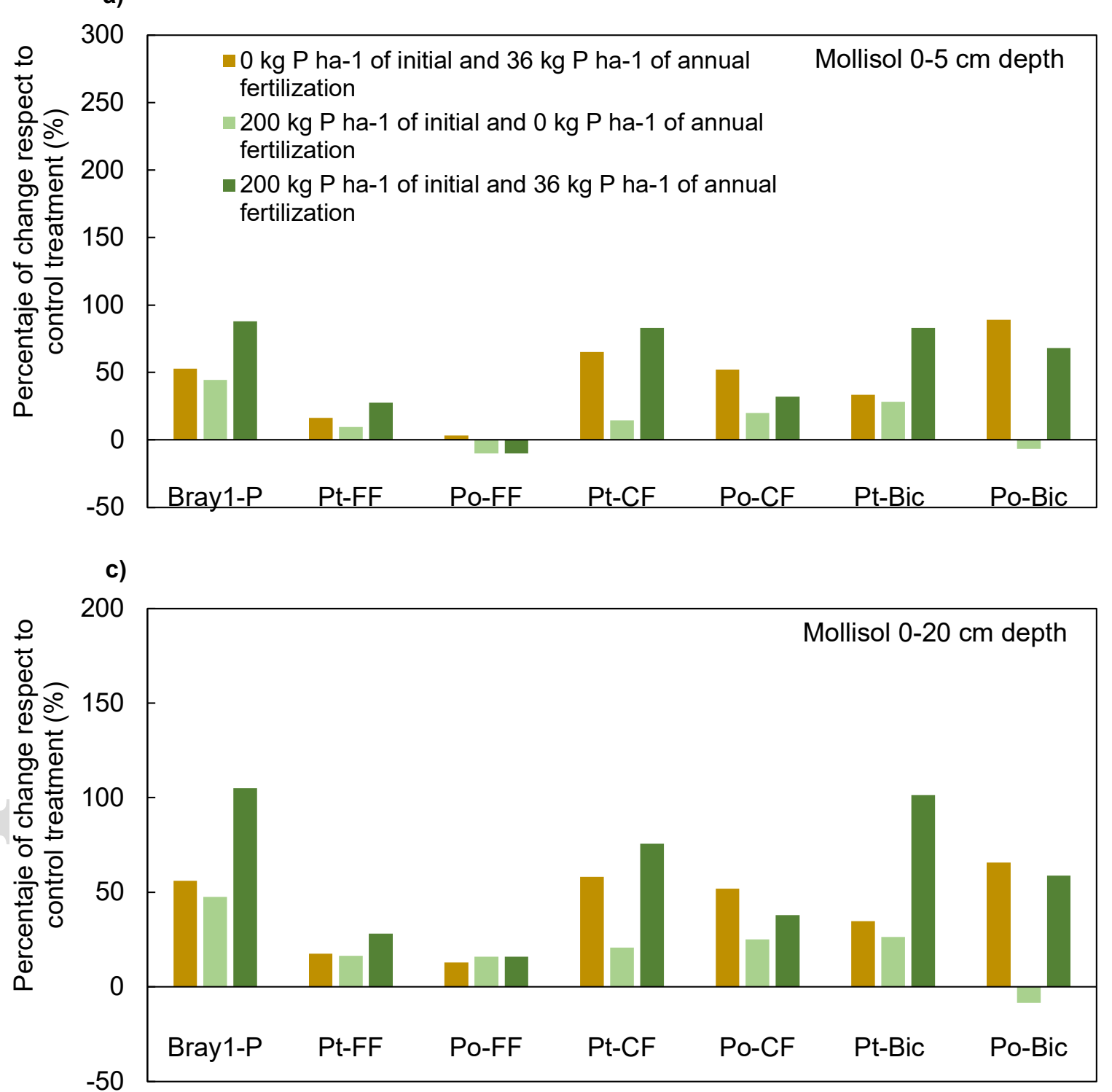

b)
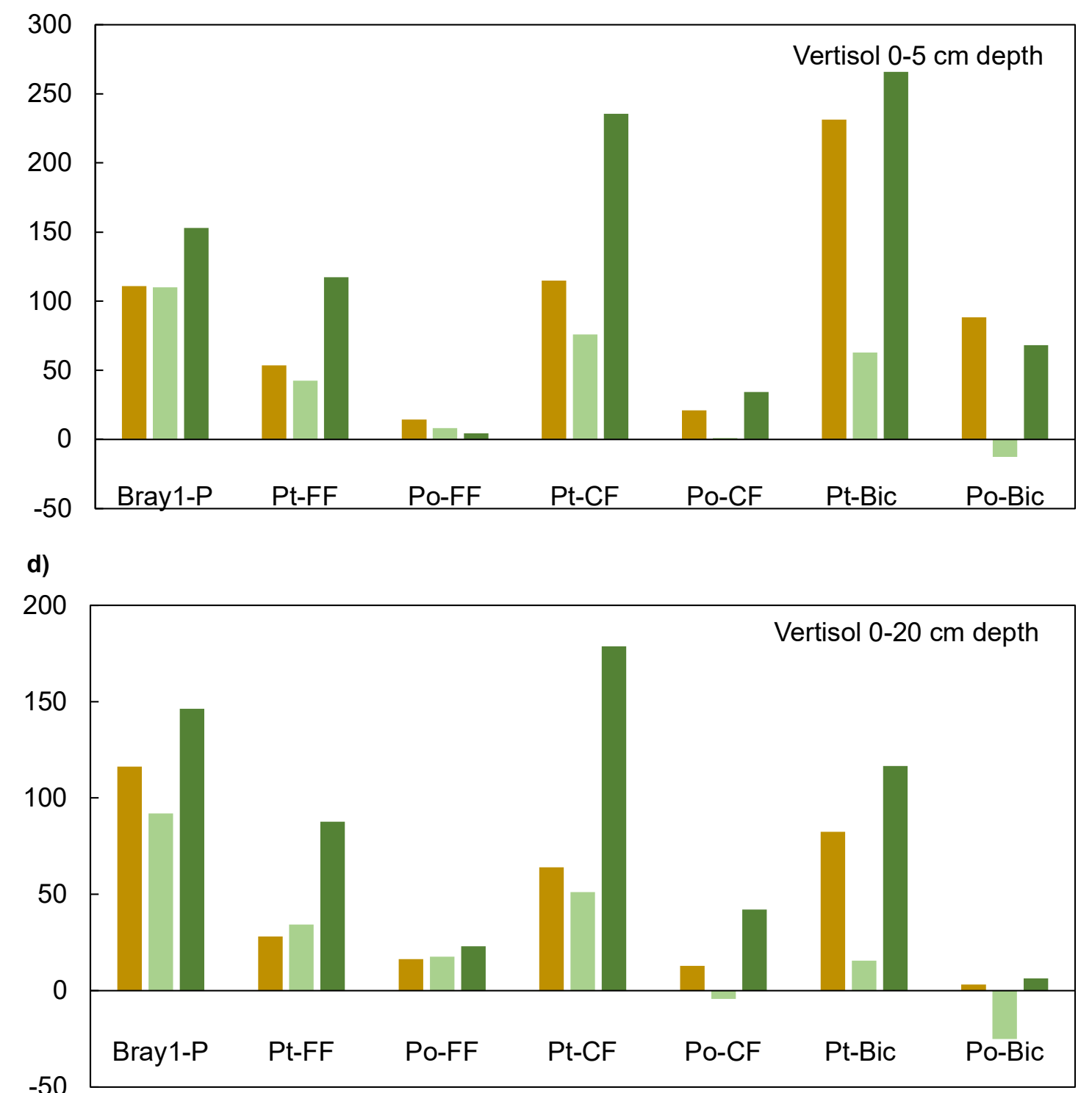

This article is protected by copyright. All rights reserved 


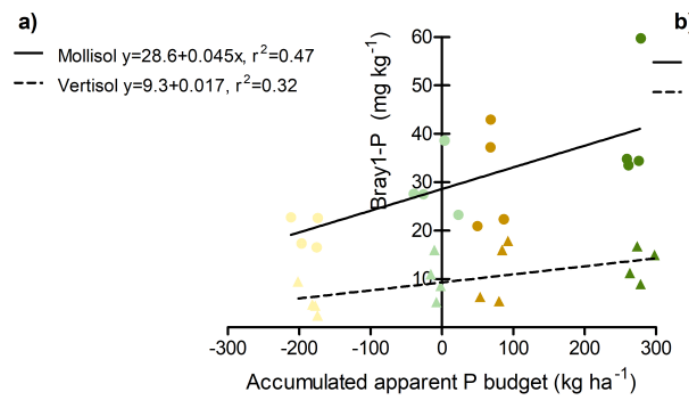

b)

c)

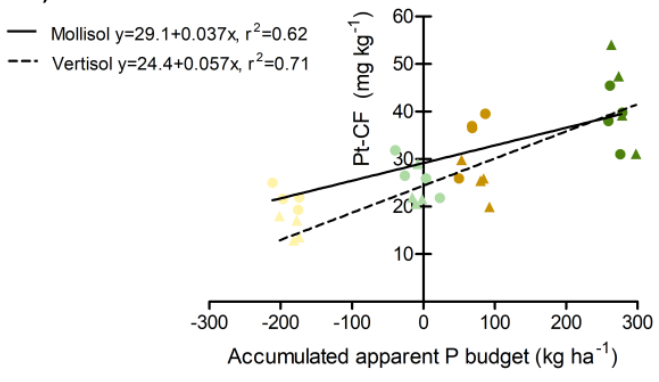

$0 \mathrm{~kg} \mathrm{Pha}{ }^{-1}$ of initial and $0 \mathrm{Pha}^{-1}$ of annual fertilization

- $200 \mathrm{~kg} \mathrm{Pha}^{-1}$ of initial and $0 \mathrm{Pha}^{-1}$ of annual fertilization
Molisol $y=17.0+0.029 x, r^{2}=0.61$

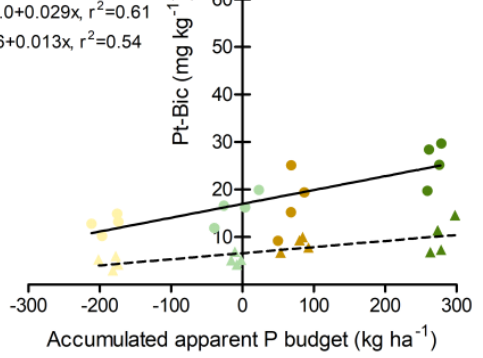

d)

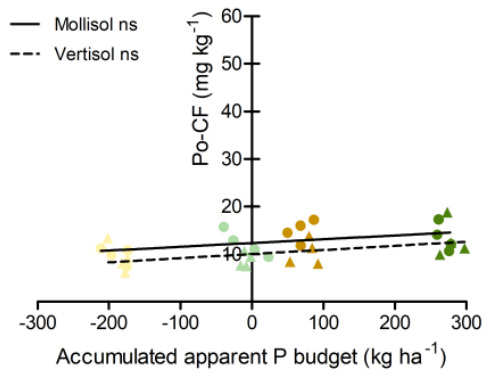

- $0 \mathrm{~kg} \mathrm{Pha}{ }^{-1}$ of initial and $36 \mathrm{Pha}^{-1}$ of annual fertilization

- $200 \mathrm{~kg} \mathrm{Pha}^{-1}$ of initial and $36 \mathrm{Pha}^{-1}$ of annual fertilization

sum_12581-2019-134_f2.tif 

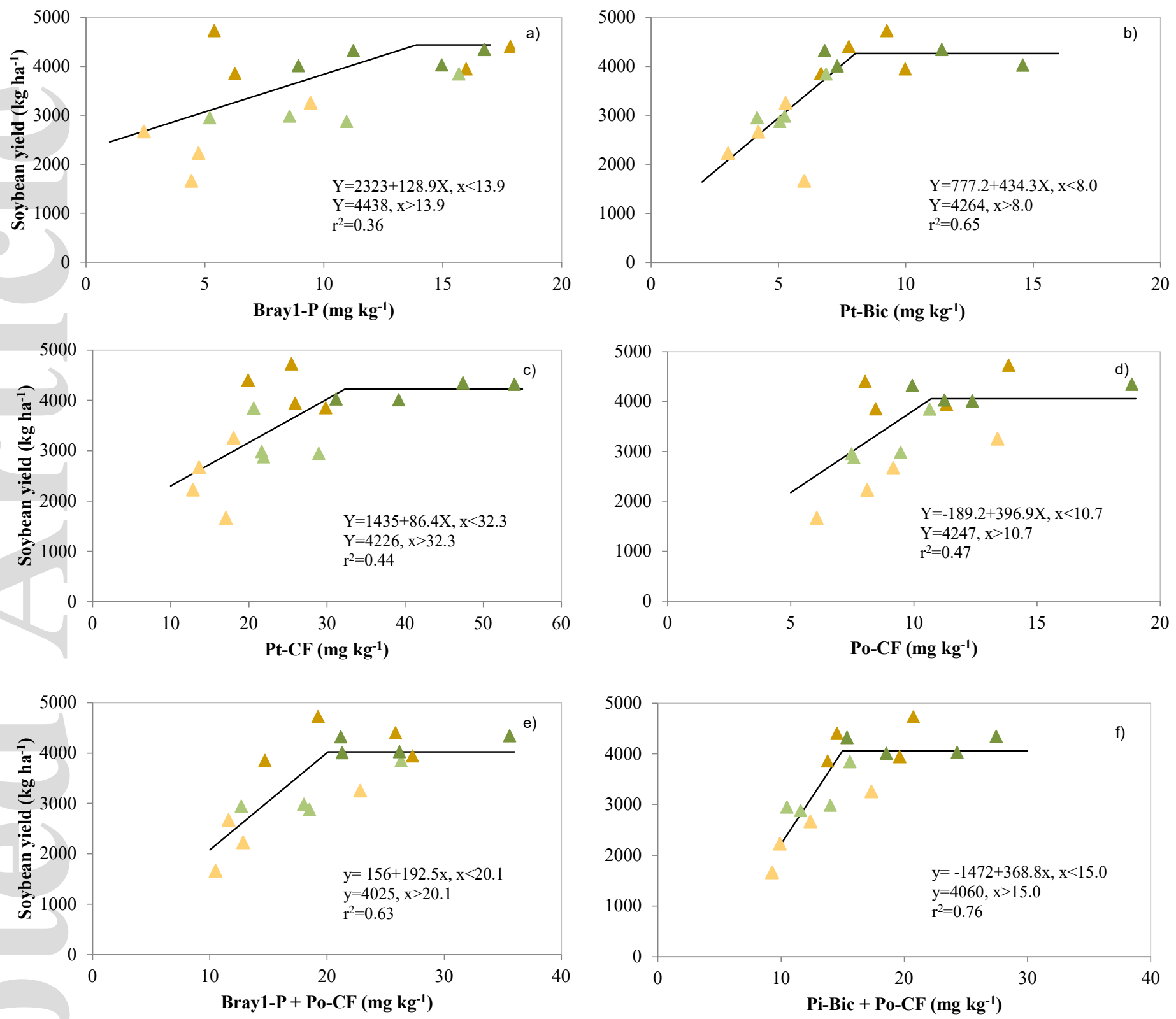

$\triangle 0 \mathrm{~kg}$ P ha-1 of initial and $0 \mathrm{~kg} \mathrm{P}$ ha-1 of annual fertilization

$\triangle 0 \mathrm{~kg}$ P ha-1 of initial and $36 \mathrm{~kg} \mathrm{P}$ ha- 1 of annual fertilization $200 \mathrm{~kg}$ P ha-1 of initial and $0 \mathrm{~kg}$ P ha- 1 of annual fertilization $\triangle 200 \mathrm{~kg}$ P ha-1 of initial and $36 \mathrm{~kg}$ P ha-1 of annual fertilization 